CLINICAL STUDY

\title{
Type 1 and type 2 iodothyronine deiodinases in the thyroid gland of patients with $3,5,3^{\prime}$-triiodothyronine-predominant Graves' disease
}

Mitsuru Ito, Nagaoki Toyoda ${ }^{1}$, Emiko Nomura ${ }^{1}$, Yuuki Takamura, Nobuyuki Amino, Toshiji Iwasaka ${ }^{1}$, Junta Takamatsu ${ }^{2}$, Akira Miyauchi and Mitsushige Nishikawa ${ }^{1}$

Kuma Hospital, Kobe, Hyogo 650-0011, Japan, ${ }^{1}$ Internal Medicine II, Kansai Medical University, 2-3-1, Shinmachi, Hirakata City, Osaka 573-1191, Japan and ${ }^{2}$ Takamatsu Clinic, Osaka 569-0804, Japan

(Correspondence should be addressed to N Toyoda; Email: toyoda@takii.kmu.ac.jp)

\begin{abstract}
Objective: 3,5,3'-triiodothyronine-predominant Graves' disease ( $\left.\mathrm{T}_{3}-\mathrm{P}-\mathrm{GD}\right)$ is characterized by a persistently high serum $\mathrm{T}_{3}$ level and normal or even lower serum thyroxine $\left(\mathrm{T}_{4}\right)$ level during antithyroid drug therapy. The source of this high serum $\mathrm{T}_{3}$ level has not been clarified. Our objective was to evaluate the contribution of type 1 and type 2 iodothyronine deiodinase (D1 (or DIO1) and D2 (or DIO2) respectively) in the thyroid gland to the high serum $\mathrm{T}_{3}$ level in $\mathrm{T}_{3}-\mathrm{P}-\mathrm{GD}$.

Methods: We measured the activity and mRNA level of both D1 and D2 in the thyroid tissues of patients with $\mathrm{T}_{3}$-P-GD $(n=13)$ and common-type GD (CT-GD) $(n=18)$ who had been treated with methimazole up until thyroidectomy.

Results: Thyroidal D1 activity in patients with T3-P-GD $(492.7 \pm 201.3 \mathrm{pmol} / \mathrm{mg}$ prot per $\mathrm{h})$ was significantly higher $(P<0.05)$ than that in patients with CT-GD $(320.7 \pm 151.9 \mathrm{pmol} / \mathrm{mg}$ prot per $\mathrm{h})$. On the other hand, thyroidal D2 activity in patients with $\mathrm{T}_{3}-\mathrm{P}-\mathrm{GD}(823.9 \pm 596.4 \mathrm{fmol} / \mathrm{mg} \mathrm{prot}$ per $\mathrm{h})$ was markedly higher $(P<0.005)$ than that in patients with CT-GD $(194.8 \pm 131.6 \mathrm{fmol} / \mathrm{mg}$ prot per $\mathrm{h}$ ). There was a significant correlation between the thyroidal $\mathrm{D} 1$ activity in patients with $\mathrm{T}_{3}-\mathrm{P}-$ GD and CT-GD and the serum $\mathrm{FT}_{3}$-to- $\mathrm{FT}_{4}$ ratio $(r=0.370, P<0.05)$. Moreover, there was a strong correlation between the thyroidal $\mathrm{D} 2$ activity in those patients and the serum $\mathrm{FT}_{3}$-to- $\mathrm{FT}_{4}$ ratio $(r=0.676, P<0.001)$.

Conclusions: Our results suggest that the increment of thyroidal deiodinase activity, namely D1 and especially D2 activities, may be responsible for the higher serum $\mathrm{FT}_{3}$-to-FT 4 ratio in $\mathrm{T}_{3}-\mathrm{P}-\mathrm{GD}$.
\end{abstract}

European Journal of Endocrinology 164 95-100

\section{Introduction}

The monodeiodination of thyroxine $\left(\mathrm{T}_{4}\right)$ to $3,5,3^{\prime}$ triiodothyronine $\left(\mathrm{T}_{3}\right)$ activates the major secretory product of the iodine-sufficient human thyroid gland, producing $\sim 80 \%$ of the circulating $\mathrm{T}_{3}$ in humans (1). Type 1 and type 2 iodothyronine deiodinase (D1 (or DIO1) and D2 (or DIO2) respectively) catalyze this reaction (2-4). The roles of D1 and D2 in the production of circulating $\mathrm{T}_{3}$ in humans are unknown. Both $\mathrm{D} 1$ and D2 activities are demonstrated in the human thyroid, and Salvatore et al. (5) reported that intrathyroidal $\mathrm{T}_{4}$ to $\mathrm{T}_{3}$ conversion by $\mathrm{D} 2$ may contribute to the relative increase in thyroidal $\mathrm{T}_{3}$ production in patients with Graves' disease (GD). On the other hand, Laurberg et al. (6) estimated by an indirect method using propylthiouracil (PTU) that D1-generated $\mathrm{T}_{3}$ in the thyroid gland is the major source of plasma $\mathrm{T}_{3}$ in hyperthyroid humans. Recently, some cases of relatively high serum $\mathrm{T}_{3}$ levels were reported in patients with follicular thyroid carcinoma (7), GD during PTU treatment (8), thyroglobulin $(\mathrm{Tg})$ gene mutations (9), and McCuneAlbright syndrome (10). In these cases, D2 activity in the thyroid tissues was increased, and the $T_{4}$ to $T_{3}$ conversion catalyzed by D2 was assumed to be responsible for the $\mathrm{T}_{3}$ toxicosis.

In most patients with hyperthyroid GD, the elevated serum $\mathrm{T}_{4}$ and $\mathrm{T}_{3}$ levels decrease to within their respective normal ranges after appropriate antithyroid drug therapy is initiated. However, we (11) and other investigators $(12,13)$ have noted that in $\sim 12 \%$ of patients with GD, serum $\mathrm{T}_{3}$ levels remain raised, while serum $\mathrm{T}_{4}$ levels become normal or even low. We have termed this phenomenon $\mathrm{T}_{3}$-predominant $\mathrm{GD}$ ( $\mathrm{T}_{3}$-P-GD) (11). Previously, we reported that the $\mathrm{T}_{4}$ $5^{\prime}$-deiodinating activity in the thyroid tissues of patients with $\mathrm{T}_{3}-\mathrm{P}-\mathrm{GD}$ was higher than that in patients with common-type GD (CT-GD) (11). In our previous study, we used $5 \mu \mathrm{M} \mathrm{T}_{4}$ as a substrate, an amount appropriate for human D1, but 100- to 1000-fold higher than that 
for D2, thus obscuring the contributions of the D2 pathway to $\mathrm{T}_{3}$ production. Therefore, to investigate the relative roles of thyroidal D1 and D2 in the establishment of a higher serum free $\mathrm{T}_{3}\left(\mathrm{FT}_{3}\right)$ relative to serum free $\mathrm{T}_{4}\left(\mathrm{FT}_{4}\right)$ in patients with $\mathrm{T}_{3}-\mathrm{P}-\mathrm{GD}$, we evaluated thyroidal activities and mRNA levels of both D1 and D2 in patients with $\mathrm{T}_{3}-\mathrm{P}-\mathrm{GD}$ and CT-GD.

\section{Materials, subjects, and methods}

\section{Materials}

$\left[{ }^{125} \mathrm{I}\right] \mathrm{T}_{4}$ and $\left[{ }^{125} \mathrm{I}\right] \mathrm{T}_{3}$ (reverse $\mathrm{T}_{3}$ or $\mathrm{rT}_{3}$ ) were purchased from Perkin Elmer (Boston, MA, USA). Sephadex LH-20 was purchased from Pharmacia Biotech. All other chemicals were of the highest quality and were obtained from Sigma Chemical Co. or Nakalai Tesque (Kyoto, Japan) unless otherwise indicated.

\section{Subjects}

We studied 13 patients with $\mathrm{T}_{3}-\mathrm{P}-\mathrm{GD}$ and 18 patients with CT-GD who had undergone thyroidectomy between January, 2007 and October, 2007 at Kuma Hospital. GD was diagnosed on the basis of clinical findings and laboratory tests showing high serum $\mathrm{FT}_{4}$ and $\mathrm{FT}_{3}$ levels, low TSH concentrations, increased anti-TSH receptor antibody (TRAb) titer, and a high radioactive iodine uptake. At the time of surgery, while the serum $\mathrm{FT}_{4}$ levels in the patients with $\mathrm{T}_{3}-\mathrm{P}-\mathrm{GD}$ declined to normal or low during methimazole (MMI) treatment, their serum $\mathrm{FT}_{3}$ levels remained high or relatively high for more than 3 months. Their serum $\mathrm{FT}_{3}$-to- $\mathrm{FT}_{4}$ ratios were all above the normal range. In the patients with CT-GD, MMI treatment resulted in a decline in both serum $\mathrm{FT}_{4}$ and $\mathrm{FT}_{3}$ levels to within the normal range and a decline in $\mathrm{FT}_{3}-$ to- $\mathrm{FT}_{4}$ ratios to within the normal range. The mean dose of MMI was $25 \pm 10 \mathrm{mg} /$ day in the patients with $\mathrm{T}_{3}-\mathrm{P}-\mathrm{GD}$ and $7 \pm 3 \mathrm{mg} /$ day in the patients with CT-GD. This study was approved by the ethics committee at Kuma Hospital, and all the patients gave informed consent.

\section{Thyroid function tests}

Serum concentrations of $\mathrm{TSH}, \mathrm{FT}_{4}$, and $\mathrm{FT}_{3}$ were measured with a chemiluminescent immunoassay (ARCHTECT i2000; Abbott Japan). Serum TRAb titer levels were measured using a human radioreceptor assay (DYNO test; Yamasa Co., Tokyo, Japan) (14) with a reference range of $<1.0 \mathrm{IU} / \mathrm{l}$. Thyroid-stimulating antibody (TSAb) titer levels were measured in terms of the amount of cAMP produced in cultured porcine thyroid cells (Yamasa Co.) with a reference range of $<180 \%$ (15). The volume of the thyroid gland was measured by ultrasonography as reported previously (16).

\section{5 ' deiodinase assays}

Human thyroid tissues were homogenized, and a microsomal fraction was prepared as described previously (5). D1 and D2 activities were assayed as described previously (5). In brief, the reactions contained microsomal protein, $0.1 \mathrm{nM}\left[{ }^{125} \mathrm{I}\right] \mathrm{T}_{4}$ purified by LH-20 chromatography, $2 \mathrm{nM}$ cold $\mathrm{T}_{4}, 20 \mathrm{mM}$ dithiothreitol (DTT), $1 \mathrm{mM}$ PTU in $0.1 \mathrm{M}$ potassium phosphate, and $1 \mathrm{mM}$ EDTA, pH 6.9 (D2 conditions) or $0.2 \mathrm{nM}\left[{ }^{125} \mathrm{I}\right] \mathrm{rT}_{3}$ purified by LH-20 chromatography, $1 \mu \mathrm{M} \mathrm{rT}$, and $10 \mathrm{mM}$ DTT in the presence or absence of $1 \mathrm{mM}$ PTU (D1 conditions). Incubations were for $120 \mathrm{~min}$ (D2 conditions) or $60 \mathrm{~min}$ (D1 conditions) at $37^{\circ} \mathrm{C} .{ }^{125} \mathrm{I}^{-}$ was separated from unreacted substrate or iodothyronine products by trichloroacetic acid precipitation. Separated ${ }^{125} \mathrm{I}^{-}$was counted with a gamma-counter. The deiodinating activity was expressed in picomoles (D1) or femtomoles (D2) of $\mathrm{I}^{-}$released per mg protein/h. Deiodination of $\mathrm{T}_{4}$ and $\mathrm{rT}_{3}$ produced equimolar concentrations of labeled $\mathrm{I}^{-}$and $\mathrm{T}_{3}$ (from $\mathrm{T}_{4}$ ) or 3,3'-diiodothyronine (from $\mathrm{rT}_{3}$ ) as assessed by paper chromatographic separation of the reaction products (17).

\section{RNA preparation and real-time quantitative PCR}

Total RNA from thyroid tissues was isolated using TRIzol reagent (Invitrogen) according to the manufacturer's protocol. Real-time quantitative PCR assays were performed using an Opticon 2 apparatus (Bio-Rad Lab.). Briefly, $1 \mu \mathrm{g}$ total RNA was reverse transcribed using the iScript cDNA synthesis kit (Bio-Rad Lab.) according to the manufacturer's instructions. Human D1, D2, and glyceraldehyde-3-phosphate dehydrogenase (GAPDH) mRNA levels were analyzed using the iQ SYBR Green Super MIX (Bio-Rad Lab.). The primers were as follows: 5'-TTAGTTCCATAGCAGATTTTCTTGTCA-3' (sense) and 5'-CTGATGTCCATGTTGTTCTTAAAAGC-3' (antisense) amplify the human D1 cDNA; 5'-TCATTCTGCTCAAGCACGTG-3' (sense) and 5'-ACCATTGCCACTGTTGTCAC- $3^{\prime}$ (antisense) amplify the human D2 cDNA; and 5'-GCACCGTCAAGGCTGAGAAC-3' (sense) and 5'-TGGTGAAGACGCCAGTGGA-3' (antisense) amplify the human GAPDH cDNA. Real-time PCR experiments were performed in triplicate, and mRNA levels were expressed as arbitrary units after correction for GAPDH mRNA level.

\section{Statistical analysis}

Group data were expressed as means \pm s.D., and statistical significance was analyzed by the unpaired t-test or the Mann-Whitney $U$ test, as appropriate. Correlations were analyzed by Pearson's correlation coefficient test. $P$ values $<0.05$ were considered to indicate a significant difference. 


\section{Results}

\section{Clinical findings}

Some basic characteristics of the 13 patients with $\mathrm{T}_{3}$-P-GD and the 18 patients with CT-GD who completed the study are listed in Table 1. These measurements were made at the time of the thyroidectomy. The differences in the serum levels of TSH and $\mathrm{FT}_{4}$ were not statistically significant. As expected, the patients with $\mathrm{T}_{3}-\mathrm{P}-\mathrm{GD}$ had a higher mean serum $\mathrm{FT}_{3}$ level and $\mathrm{FT}_{3}$-to- $\mathrm{FT}_{4}$ ratio than the patients with CT-GD. The mean TRAb and TSAb levels were greater in the patients with $\mathrm{T}_{3}-\mathrm{P}-\mathrm{GD}$. The mean volume of the thyroid gland was approximately seven times higher in the patients with $\mathrm{T}_{3}-\mathrm{P}-\mathrm{GD}$. After thyroidectomy and an appropriate dose of $\mathrm{L}_{-} \mathrm{T}_{4}$ administration, serum $\mathrm{FT}_{4}$ and $\mathrm{FT}_{3}$ levels in the patients with $\mathrm{T}_{3}-\mathrm{P}-\mathrm{GD}$ changed to within the normal range $\left(1.21 \pm 0.15 \mathrm{ng} / \mathrm{dl}\left(\mathrm{FT}_{4}\right)\right.$ and $2.12 \pm 0.27\left(\mathrm{FT}_{3}\right)$ respectively), and the $\mathrm{FT}_{3}$-to- $\mathrm{FT}_{4}$ ratio declined to $1.78 \pm 0.33$.

\section{$D 1$ and $D 2$ activities in thyroid tissues}

The D1 activity in thyroid tissues of the patients with $\mathrm{T}_{3}$-P-GD (492.7 $\pm 201.3 \mathrm{pmol} / \mathrm{mg}$ prot per $\left.\mathrm{h}\right)$ was significantly higher $(P<0.05)$ than that in the patients with CT-GD (320.7 $\pm 151.9 \mathrm{pmol} / \mathrm{mg}$ prot per h; Fig. 1). The D2 activity in thyroid tissues of the patients with $\mathrm{T}_{3}$-P-GD (823.9 $\pm 596.4 \mathrm{fmol} / \mathrm{mg}$ prot per $\left.\mathrm{h}\right)$ was markedly higher $(P<0.005)$ than that in the patients with CT-GD (194.8 $\pm 131.6 \mathrm{fmol} / \mathrm{mg}$ prot per h; Fig. 1).

To investigate whether thyroidal D1 and D2 contribute to the $\mathrm{FT}_{3}$-to- $\mathrm{FT}_{4}$ ratio, we investigated the correlation between the serum $\mathrm{FT}_{3}$-to- $\mathrm{FT}_{4}$ ratio and the corresponding thyroidal D1 and D2 activities. As shown in Fig. 2A, the D1 activity of patients with $\mathrm{T}_{3}$-P-GD and CT-GD significantly correlated with the

Table 1 Basic characteristics of patients with $T_{3}-P-G D$ and CT-GD who completed the study. The normal ranges were $0.3-5.0 \mu \mathrm{IU} / \mathrm{m}$ for TSH, $0.7-1.6 \mathrm{ng} / \mathrm{dl}$ for free thyroxine $\left(\mathrm{FT}_{4}\right), 1.7-3.7 \mathrm{pg} / \mathrm{ml}$ for free $\mathrm{T}_{3}\left(\mathrm{FT}_{3}\right)$, and 1.8-3.3 $((\mathrm{pg} / \mathrm{ml}) /(\mathrm{ng} / \mathrm{dl}))$ for the $\mathrm{FT}_{3}$-to- $\mathrm{FT}_{4}$ ratio. A TSH concentration $<0.003 \mu \mathrm{lU} / \mathrm{ml}$ was regarded as 0 , for the purpose of statistical calculation. Values shown are means \pm S.D. Values in patients with $T_{3}-P-G D$ and CT-GD were compared using the unpaired $t$-test or the Mann-Whitney $U$ test, as appropriate.

\begin{tabular}{lccr}
\hline & T $_{3}$-P-GD $(n=13)$ & CT-GD $(n=18)$ & $\boldsymbol{P}$ value \\
\hline Age & $36 \pm 12$ & $49 \pm 16$ & 0.008 \\
Gender (F/M) & $10 / 3$ & $15 / 3$ & 0.676 \\
Dose of MMl (mg) & $25 \pm 10$ & $7 \pm 3$ & $<0.001$ \\
$\mathrm{TSH}_{(\mu l \mathrm{l} / \mathrm{ml})}$ & $2.50 \pm 5.05$ & $2.03 \pm 2.05$ & 0.754 \\
$\mathrm{FT}_{4}(\mathrm{ng} / \mathrm{dl})$ & $0.89 \pm 0.79$ & $0.87 \pm 0.15$ & 0.919 \\
$\mathrm{FT}_{3}(\mathrm{pg} / \mathrm{ml})$ & $4.72 \pm 3.65$ & $2.35 \pm 0.42$ & 0.038 \\
$\mathrm{FT}_{3} / \mathrm{FT}_{4}$ & $6.6 \pm 3.0$ & $2.7 \pm 0.5$ & 0.001 \\
$\mathrm{TRAb}_{4}(\mathrm{U} / \mathrm{l})$ & $206 \pm 276$ & $5.04 \pm 4.68$ & $<0.001$ \\
TSAb (\%) & $1124 \pm 582$ & $350 \pm 338$ & $<0.001$ \\
Thyroid volume (ml) & $227 \pm 106$ & $32 \pm 23$ & $<0.001$ \\
\hline
\end{tabular}

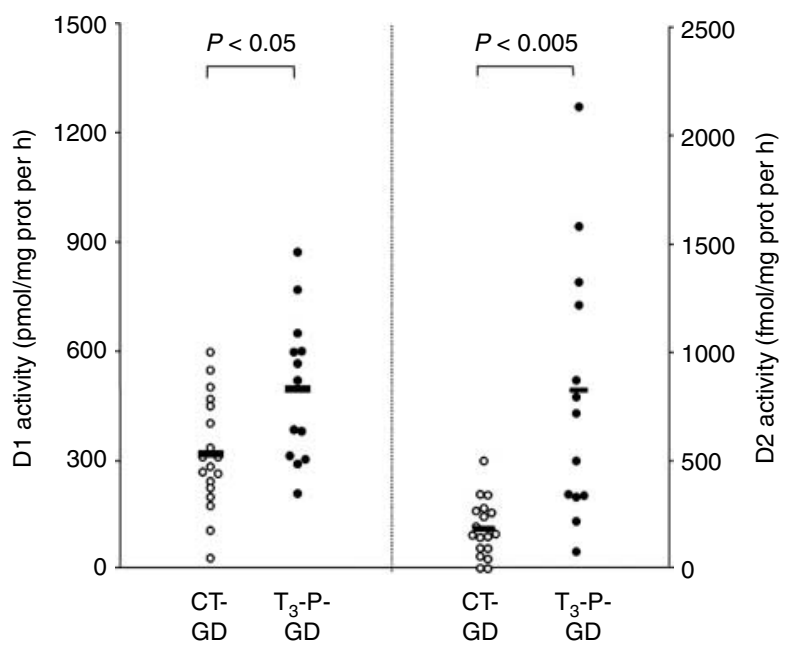

Figure $1 \mathrm{D} 1$ and $\mathrm{D} 2$ activities in thyroid tissues. Open circles represent CT-GD patients; closed circles represent $T_{3}-P-G D$ patients; solid squares represent mean value levels.

serum $\mathrm{FT}_{3}$-to- $\mathrm{FT}_{4}$ ratio $(r=0.370, P<0.05)$. Meanwhile, the D2 activity of those patients strongly correlated with the serum $\mathrm{FT}_{3}$-to- $\mathrm{FT}_{4}$ ratio $(r=0.676$, $P<0.001$; Fig. 2B).

Furthermore, we investigated the correlation between the serum TRAb titer level and the corresponding thyroidal D1 and D2 activities. The thyroidal D1 activity of patients with $\mathrm{T}_{3}-\mathrm{P}-\mathrm{GD}$ and CT-GD significantly correlated with the serum TRAb titer level $(r=0.502$, $P<0.01)$. The thyroidal D2 activity of those patients also significantly correlated with the serum TRAb titer level $(r=0.502, P<0.01)$.

\section{D1 and D2 mRNA in thyroid tissues}

We investigated the thyroidal D1 and D2 mRNA. The thyroidal $D 1$ mRNA level in the patients with $\mathrm{T}_{3}-\mathrm{P}-\mathrm{GD}$ $(0.028 \pm 0.015$ arbitrary unit) was significantly higher than that in the patients with CT-GD (0.016 \pm 0.014 arbitrary unit; Fig. 3). On the other hand, there was no significant difference between the thyroidal D2 mRNA level in the patients with $\mathrm{T}_{3}$-P-GD (0.545 \pm 0.276 arbitrary unit) and that in the patients with CT-GD $(0.494 \pm 0.234$ arbitrary unit; Fig. 3).

Next, we examined whether D1 and D2 activities correlated with the corresponding mRNA level. There was a significant correlation between the D1 activity and the D1 mRNA level in the thyroid tissues from $\mathrm{T}_{3}$-P-GD and CT-GD patients $(r=0.502, \quad P<0.01)$. On the other hand, there was no significant correlation between the D2 activity and the D2 mRNA level in the thyroid tissues from those patients $(r=0.362$, $P=0.076)$. 

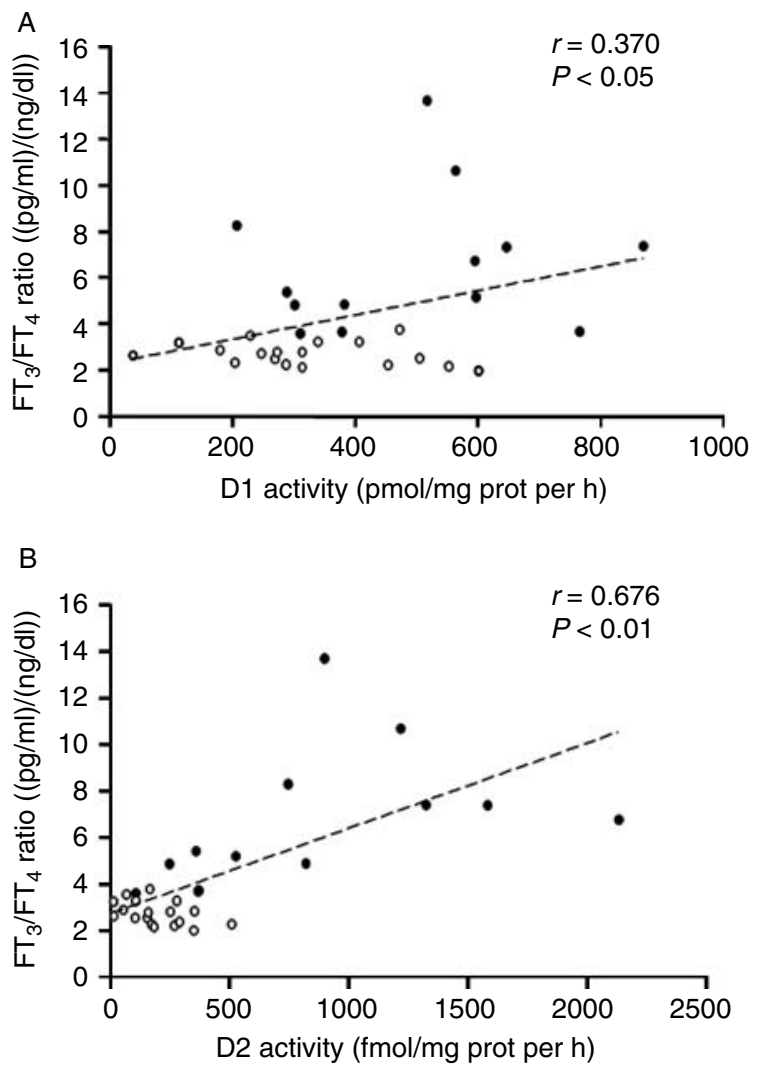

Figure 2 Correlation between thyroidal D1 (A) and D2 (B) activities and $\mathrm{FT}_{3}$-to- $\mathrm{FT}_{4}$ ratio. Open circles represent CT-GD patients; closed circles represent $T_{3}-P-G D$ patients.

Furthermore, we investigated the correlation between the serum TRAb titer level and the corresponding thyroidal D1 and D2 mRNA level. There was a significant correlation between the thyroidal D1 mRNA level and the serum TRAb titer level in the patients with $\mathrm{T}_{3}$-P-GD and CT-GD $(r=0.651, P<0.01)$. On the other hand, there was a significant but weak correlation between the thyroidal D2 mRNA level and the serum TRAb titer level in those patients $(r=0.489$, $P<0.05)$.

\section{Discussion}

The serum $\mathrm{FT}_{4}$ and $\mathrm{FT}_{3}$ levels and $\mathrm{FT}_{3}$-to- $\mathrm{FT}_{4}$ ratio in the patients with $\mathrm{T}_{3}-\mathrm{P}-\mathrm{GD}$ changed to within the almost normal range after thyroidectomy and administration of the appropriate dose of $\mathrm{L}_{-} \mathrm{T}_{4}$. Therefore, it was suggested that $\mathrm{T}_{3}$ production from the thyroid mainly contributed to the elevated serum $\mathrm{T}_{3}$ level in $\mathrm{T}_{3}$-P-GD. $\mathrm{T}_{3}$ production from the thyroid is thought to originate from deiodination of $\mathrm{T}_{4}$ in the thyroid and from the hydrolysis of $\mathrm{Tg}$. It is thought that the thyroid gland deiodinates both $\mathrm{T}_{4}$ released from $\mathrm{Tg}$ and $\mathrm{T}_{4}$ taken up from the vascular bed (18).

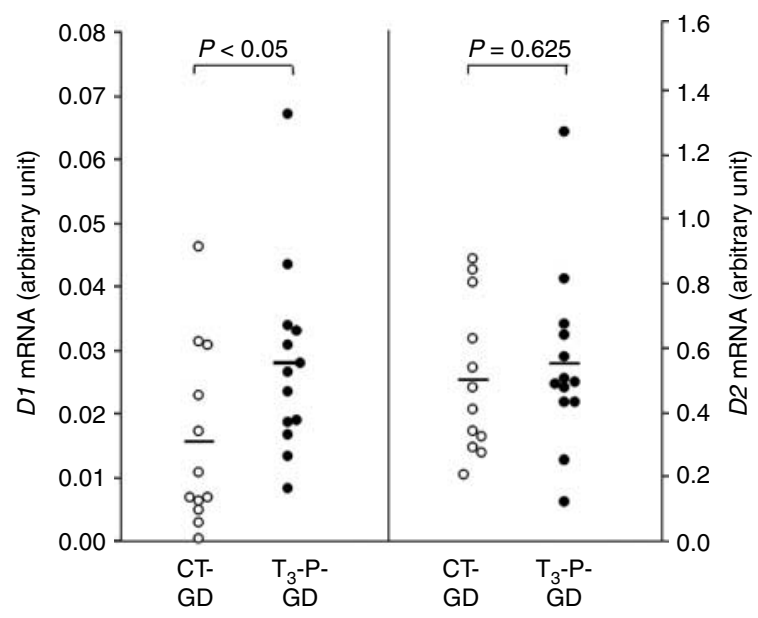

Figure $3 D 1$ and $D 2$ mRNA in thyroid tissues. Open circles represent CT-GD patients; closed circles represent $T_{3}$-P-GD patients; solid squares represent mean value levels.

We demonstrated that the deiodinase activities of D1 and especially D2 in the thyroid tissues of $\mathrm{T}_{3}$-P-GD were significantly higher than those of CT-GD. Increased D2 activity of the thyroid tissues was also observed in some cases of $\mathrm{T}_{3}$ thyrotoxicosis such as follicular thyroid carcinoma, GD during PTU treatment, TG gene mutations, and McCune-Albright syndrome (7-10). Laurberg et al. suggested that D1-generated $\mathrm{T}_{3}$ in the thyroid was a major part of the total $\mathrm{T}_{3}$ production in untreated GD (6). However, in $\mathrm{T}_{3}-\mathrm{P}-\mathrm{GD}$ patients who were treated with MMI, the serum $\mathrm{FT}_{4}$ level was within the normal range, while the serum $\mathrm{FT}_{3}$ level was elevated. Therefore, we suggest that the mechanism(s) by which elevated serum $\mathrm{FT}_{3}$ levels are maintained in the patients with $\mathrm{T}_{3}-\mathrm{P}-\mathrm{GD}$ probably differ from those in the patients with untreated GD. Although we have neither direct nor indirect results to indicate which deiodinase is responsible for the elevated serum $\mathrm{T}_{3}$ level in $\mathrm{T}_{3}$-P-GD, the closer correlation between thyroidal D2 activity and serum $\mathrm{FT}_{3}$-to- $\mathrm{FT}_{4}$ ratio favors thyroidal $\mathrm{D} 2$ as the cause, but this is not definitive.

It is predicted that D1 activity in the liver and kidney might be increased in $\mathrm{T}_{3}-\mathrm{P}-\mathrm{GD}$, as $\mathrm{D} 1$ is positively regulated by $\mathrm{T}_{3}$ (19). Maia et al. (21) estimated that $\mathrm{D} 2$ is the major contributor of extrathyroidal $\mathrm{T}_{3}$ production in euthyroid subjects, and peripheral $\mathrm{T}_{3}$ production may switch from D2 to D1 dependency in thyrotoxic patients, since the D2 activity decreases due to the posttranslational substrate-induced inactivation of D2 $(20,21)$. In this study, since the serum $\mathrm{FT}_{4}$ level in the patients with $\mathrm{T}_{3}-\mathrm{P}-\mathrm{GD}$ was within the normal range, we considered that $\mathrm{D} 2$-generated $\mathrm{T}_{3}$ mainly contributes to the extrathyroidal $\mathrm{T}_{3}$ production in the patients with $\mathrm{T}_{3}$-P-GD. Therefore, it is suggested that any change in D1 activity in the liver and kidney of $\mathrm{T}_{3}$-P-GD patients would contribute little to the peripheral $\mathrm{T}_{3}$ production, even if $\mathrm{D} 1$ activity is increased in $\mathrm{T}_{3}-\mathrm{P}-\mathrm{GD}$. 
D2 mRNA is positively regulated by cAMP via cAMPresponsive element in the human $D 2$ gene $(22,23)$ and negatively regulated by $\mathrm{T}_{3}$ at pretranslational level $(24$, $25)$. In this study, the correlation between the thyroidal D2 mRNA level and the TRAb titer in the patients with $\mathrm{T}_{3}$-P-GD and CT-GD was weak. These results suggest that not only positive regulation by cAMP, which is produced in the thyroid cells by TRAb stimulation, but also negative regulation by $\mathrm{T}_{3}$ may also regulate the thyroidal D2 mRNA level in those patients. Further investigations are necessary to clarify the mechanism(s) by which thyroidal $D 2$ mRNA is regulated.

Although the thyroidal D2 activity in the patients with $\mathrm{T}_{3}-\mathrm{P}-\mathrm{GD}$ was significantly higher than that in the patients with CT-GD, there was no significant difference between the thyroidal D2 mRNA level in the patients with $\mathrm{T}_{3}-\mathrm{P}-\mathrm{GD}$ and that in the patients with CT-GD. Furthermore, there was no significant correlation between the thyroidal D2 activity and the D2 mRNA level in those patients. It is well known that D2 activity is negatively regulated at the posttranslational level by its preferred substrate $\mathrm{T}_{4}$ via the stimulation of the ubiquitin-mediated proteasome degradation of the enzyme (20). There was no significant difference between the serum $\mathrm{FT}_{4}$ level in the patients with $\mathrm{T}_{3}-\mathrm{P}-\mathrm{GD}$ and that in the patients with CT-GD in this study. Therefore, it is suggested that translational and/or posttranslational mechanism(s), which are not induced by $\mathrm{T}_{4}$, may be involved in the higher thyroidal $\mathrm{D} 2$ activity in the patients with $\mathrm{T}_{3}-\mathrm{P}-\mathrm{GD}$.

Interestingly, the correlation between the TRAb titer level and the thyroidal D2 activity was stronger than that between the TRAb titer level and the thyroidal $D 2$ mRNA level in the patients with $\mathrm{T}_{3}$-P-GD and CT-GD. These results suggest that TRAb may regulate the D2 activity not only at pretranslational level, but also at translational and/or posttranslational level(s).

Of note is the fact that the volume of the thyroid gland was greater in the patients with $\mathrm{T}_{3}$-P-GD. It is likely that the large goiter size is related to stimulation by higher $\mathrm{TRAb}$ in the patients with $\mathrm{T}_{3}-\mathrm{P}-\mathrm{GD}$. Interestingly, higher thyroidal D2 activities have been observed in some large goitrous thyroid diseases such as $T G$ gene mutations or McCune-Albright syndrome $(9,10)$. These findings suggest that a large goiter itself or any stimulating factor(s) that enlarge the thyroid volume may induce higher thyroidal D2 activity in the patients with $\mathrm{T}_{3}$-P-GD. Further investigations are necessary to clarify the mechanism(s) by which higher thyroidal D2 activity is induced in the patients with $\mathrm{T}_{3}-\mathrm{P}-\mathrm{GD}$.

Both the thyroidal D1 activity and the D1 mRNA level in the patients with $\mathrm{T}_{3}-\mathrm{P}-\mathrm{GD}$ were significantly higher than those in the patients with CT-GD. Furthermore, there was a significant correlation between the thyroidal D1 activity and the D1 mRNA level in the patients with $\mathrm{T}_{3}$-P-GD and CT-GD. Significant positive correlation between the thyroidal D1 mRNA level and the serum TRAb titer level was present in those patients.
These results suggest that the thyroidal D1 activity may be mainly regulated at pretranslational level by cAMP, which is produced in the thyroid cells by TRAb stimulation.

On the other hand, in our previous study, both TG and the iodine content in thyroid tissues of patients with $\mathrm{T}_{3}$-P-GD were lower than those of patients with CT-GD (26). Therefore, an enhanced iodine metabolism and possibly a higher rate of TG hydrolysis with prompt release of thyroid hormones, mostly $\mathrm{T}_{3}$, may also contribute to the higher serum $\mathrm{FT}_{3}$-to- $\mathrm{FT}_{4}$ ratio in the patients with $\mathrm{T}_{3}-\mathrm{P}-\mathrm{GD}$.

In conclusion, this study suggests that both thyroidal D1 and, especially, D2 may at least partly contribute to the higher serum $\mathrm{FT}_{3}$-to- $\mathrm{FT}_{4}$ ratio in the patients with $\mathrm{T}_{3}-\mathrm{P}-\mathrm{GD}$. Further studies are needed to clarify the mechanism(s) by which the higher serum $\mathrm{FT}_{3}$-to- $\mathrm{FT}_{4}$ ratio and higher thyroidal D1 and D2 activities are induced in the patients with $\mathrm{T}_{3}-\mathrm{P}-\mathrm{GD}$.

\section{Declaration of interest}

The authors declare that there is no conflict of interest that could be perceived as prejudicing the impartiality of the research reported.

\section{Funding}

This study was supported in part by the Smoking Research Foundation of Japan.

\section{References}

1 Larsen PR, Silva JE \& Kaplan MM. Relationships between circulating and intracellular thyroid hormones: physiological and clinical implications. Endocrine Reviews 19812 87-102. (doi:10.1210/edrv-2-1-87)

2 St Germain DL \& Galton VA. The deiodinase family of selenoproteins. Thyroid 19977 655-668. (doi:10.1089/thy.1997.7.655)

3 Bianco AC, Salvatore D, Gereben B, Berry MJ \& Larsen PR. Biochemistry, cellular and molecular biology, and physiological roles of the iodothyronine selenodeiodinases. Endocrine Reviews 200223 38-89. (doi:10.1210/er.23.1.38)

4 Kuiper GGJM, Kester MHA, Peeters RP \& Visser TJ. Biochemical mechanisms of thyroid hormone deiodination. Thyroid 200515 787-798. (doi:10.1089/thy.2005.15.787)

5 Salvatore D, Tu H, Harney JW \& Larsen PR. Type 2 iodothyronine deiodinase is highly expressed in human thyroid. Journal of Clinical Investigation 199698 962-968. (doi:10.1172/JCI118880)

6 Laurberg P, Vestergaard H, Nielsen S, Christensen SE, Seefeldt T, Helleberg K \& Pedersen KM. Source of circulating 3,5,3'-triiodothyronine in hyperthyroidism estimated after blocking type 1 and type 2 iodothyronine deiodinses. Journal of Clinical Endocrinology and Metabolism 200792 2149-2156. (doi:10.1210/jc.2007-0178)

7 Kim BW, Daniels GH, Harrison BJ, Price A, Harney JW, Larsen PR \& Weetman AP. Overexpression of type 2 iodothyronine deiodinase in follicular carcinoma as a cause of low circulating free thyroxine levels. Journal of Clinical Endocrinology and Metabolism $2003 \mathbf{8 8}$ 594-598. (doi:10.1210/jc.2002-020921)

8 Weetman AP, Shepherdley CA, Mansell P, Ubhi CS \& Visser TJ. Thyroid over-expression of type 1 and type 2 deiodinase may account for the syndrome of low thyroxine and increasing triiodothyronine during propylthiouracil treatment. European Journal of Endocrinology 2003149 443-447. (doi:10.1530/eje.0.1490443) 
9 Kanou Y, Hishinuma A, Tsunekawa K, Seki K, Mizuno Y, Fujisawa H, Imai T, Miura Y, Nagasaka T, Yamada C, Ieiri T, Murakami M \& Murata Y. Thyroglobulin gene mutations producing defective intracellular transport of thyroglobulin are associated with increased type 2 iodothyronine deiodinase activity. Journal of Clinical Endocrinology and Metabolism $2007 \mathbf{9 2}$ 1451-1457. (doi:10.1210/jc.2006-1242)

10 Celi FS, Coppotelli G, Chidakel A, Kelly M, Brillante BA, Shawker T, Cherman N, Feuillan PP \& Collins MT. The role of type 1 and type 2 $5^{\prime}$-deiodinase in the pathophysiology of the 3,5,3'-triiodothyronine toxicosis of McCune-Albright syndrome. Journal of Clinical Endocrinology and Metabolism 200893 2383-2389. (doi:10. 1210/jc.2007-2237)

11 Takamatsu J, Sugawara M, Kuma K, Kobayashi A, Matsuzuka F, Mozai T \& Hershman JM. Ratio of serum triiodothyronine to thyroxine and the prognosis of triiodothyronine-predominant Graves' disease. Annals of Internal Medicine $1984100372-375$.

12 Hegedüs L, Hansen JM, Bech K, Kampmann JP, Jensen K, Andersen E, Hansen P, Karstrup S \& Bliddal H. Thyroid stimulating immunoglobulins in Graves' disease with goiter growth, low thyroxine and increasing triiodothyronine during PTU treatment. Acta Endocrinologica $1984 \mathbf{1 0 7}$ 482-488. (doi:10.1530/acta.O. 1070482)

13 Chan JJS \& Ladenson PW. Discordant hypothyroxinemia and hypertriiodothyroninemia in treated patients with hyperthyroid Graves' disease. Journal of Clinical Endocrinology and Metabolism 198663 102-106. (doi:10.1210/jcem-63-1-102)

14 Costagliola S, Morgenthaler NG, Hoermann R, Badenhoop K, Struck J, Freitag D, Poertl S, Weglöhner W, Hollidt JM, Quadbeck B, Dumont JE, Schumm-Draeger PM, Bergmann A, Mann K, Vassart G \& Usadel KH. Second generation assay for thyrotropin receptor antibodies has superior diagnostic sensitivity for Graves' disease. Journal of Clinical Endocrinology and Metabolism 199984 90-97. (doi:10.1210/jc.84.1.90)

15 Inui T, Kouki T, Yamashiro K, Hachiya T, Ochi Y, Kajita Y, Sato Y \& Nagata A. Increase of thyroid stimulating activity in Graves' immunoglobulin-G by high polyethylene glycol concentrations using porcine thyroid cell assay. Thyroid $1998 \mathbf{8} 319-325$. (doi:10.1089/thy.1998.8.319)

16 Murakami Y, Takamatsu J, Sakane S, Kuma K \& Ohsawa N. Changes in thyroid volume in response to radioactive iodine for Graves' hyperthyroidism correlated with activity of thyroidstimulating antibody and treatment outcome. Journal of Clinical Endocrinology and Metabolism 199681 3257-3260. (doi:10. 1210/jc.81.9.3257)

17 Bellabarba D, Peterson RE \& Sterling K. An improved method for chromatography of iodothyronines. Journal of Clinical Endocrinology and Metabolism 196828 305-307. (doi:10.1210/ jcem-28-2-305)
18 Laurberg P. Thyroxine entering the thyroid gland via the vascular bed may leave the gland as triiodothyronines. Studies with perfused dog thyroid lobes. Endocrinology 1986118 895-900. (doi:10.1210/endo-118-3-895)

19 Toyoda N, Zavacki AM, Maia AL, Harney JW \& Larsen PR. A novel retinoid $\mathrm{X}$ receptor-independent thyroid hormone response element is present in the human type 1 deiodinase gene. Molecular and Cellular Biology 199515 5100-5112.

20 Gereben B, Goncalves C, Harney JW, Larsen PR \& Bianco AC. Selective proteolysis of human type 2 deiodinase: a novel ubiquitin-proteasomal mediated mechanism for regulation of hormone activation. Molecular Endocrinology $2000 \quad \mathbf{1 4}$ 1697-1708. (doi:10.1210/me.14.11.1697)

21 Maia AL, Kim BW, Huang SA, Harney JW \& Larsen PR. Type 2 iodothyronine deiodinase is the major source of plasma $\mathrm{T}_{3}$ in euthyroid humans. Journal of Clinical Investigation $2005 \mathbf{1 1 5}$ 2524-2533. (doi:10.1172/JCI25083)

22 Bartha T, Kim SW, Salvatore D, Gereben B, Tu HM, Harney JW, Rudas P \& Larsen PR. Characterization of the $5^{\prime}$-flanking and $5^{\prime}$-untranslated regions of the cyclic adenosine $3^{\prime}, 5^{\prime}$-monophosphate-responsive human type 2 iodothyronine deiodinase gene. Endocrinology 2003140 229-237. (doi:10.1210/en.141.1. 229)

23 Canettieri G, Celi FS, Baccheschi G, Salvatori L, Andreoli M \& Centanni $M$. Isolation of human type 2 deiodinase gene promoter and characterization of a functional cyclic adenosine monophosphate response element. Endocrinology $2000 \mathbf{1 4 1}$ 1804-1813. (doi:10.1210/en.141.5.1804)

24 Burmeister LA, Pachucki J \& St Germain DL. Thyroid hormones inhibit type 2 iodothyronine deiodinase in the rat cerebral cortex by both pre- and posttranslational mechanisms. Endocrinology 1997138 5231-5237. (doi:10.1210/en.138.12.5231)

25 Kim SW, Harney JW \& Larsen PR. Studies of the hormonal regulation of type $25^{\prime}$-iodothyronine deiodinase messenger ribonucleic acid in pituitary tumor cells using semiquantitative reverse transcription-polymerase chain reaction. Endocrinology 1998139 4895-4905. (doi:10.1210/en.139.12.4895)

26 Takamatsu J, Hosoya T, Naito N, Yoshimura H, Kohno Y, Tarutani O, Kuma K, Sakane S, Takeda K \& Mozai T. Enhanced thyroid iodine metabolism in patients with triiodothyronine-predominant Graves' disease. Journal of Clinical Endocrinology and Metabolism 198866 147-152. (doi:10.1210/ jcem-66-1-147)

Received 20 September 2010

Accepted 11 October 2010 